\title{
Proposal of new monitoring network of water bodies of karst groundwater in Serbia
}

\author{
Marina Poledica, Danica Stevanović \\ University of Belgrade, Faculty of Mining and Geology, Department of Hydrogeology; Đušina 7, Belgrade, Serbia; \\ e-mail: marina.poledica@rgf.rs
}

(c) 2016 Authors. This is an open access publication, which can be used, distributed and reproduced in any medium according to the Creative Commons CC-BY 4.0 License requiring that the original work has been properly cited.

Groundwater resources play a dominant role in water supply in Serbia, and to manage them properly, an assessment of their quantitative and qualitative status must be given. The concept of quality groundwater management is the implementation of EU Water Framework Directive (WFD-2000/6/EC). In this, groundwater monitoring has the highest role, which should provide a comprehensive insight into the quantitative and qualitative characteristics of water in a particular area (Stevanović 2011). The research area in this case is karst landscapes of Serbia. The water bodies of karst groundwater have been identified in the Carpathian-Balkan Mountains of eastern Serbia and in the Dinaric area of western Serbia. Groundwaters of alluvial aquifers along the major rivers are systematically monitored, however, karst and artesian aquifers are not covered by the monitoring network. The current state of monitoring network in the karst of Serbia is, to say the least, unsatisfactory - only the spring of Mlava is observed by the Republic hydrometeorological service of Serbia. EU Water Framework Directive proposes water resource management at the level of river basins, so therefore, prior to network organization, the grouping of existing water bodies of karst groundwater was performed. The basic rule for grouping water bodies is that all bodies must belong to the same river basin and the groups provide reliable data for assessing the status of individual water bodies. Then topographical, geomorphological, hydrographic, geological and hydrogeological characteristics of the terrain were analyzed. According to Poledica (2015) and
Stevanović (2015), 25 groups of water bodies in the areas of exploration have been singled out, 13 of them in western and 12 in eastern Serbia. For each group a representative monitoring network has been determined. 104 observation facilities have been selected in the domain of quantity and 53 facilities in the quality domain. This is the total number of observation points that are further sorted by priority. Including the economic factor, it is proposed to gradually develop monitoring networks. Beginning of observation will start in a period of 5 years from now, when observation facilities of first priority (springs of water supply) will be included. The observation facilities of second priority will be included in a period of 10 years from now and those of third priority will be included by 2035 . Karst springs and purpose-built piezometers within the source where there are already wells for water supply provide the largest numbers of observation points. Also, hydrological stations are located on watercourses near karst springs where flows during the dry period of the year will be monitored. The final results are presented in the form of hydrogeological maps of Eastern and Western Serbia, which contain water bodies with observation points. These maps were made using the software package ArcGIS. On all facilities, it has been determined which parameters will continuously be monitored (content of observation) and how often (frequency of observation). The level of water will be observed continuously on the places where piezometers will be drilled. Discharge of springs will be observed each other day. Discharge regime of karst springs is 
studied enough only after many years of research. The reconstruction of monitoring network is suggested after six years. Microbiological and bacterial composition will be observed at least six times a year and other qualitative parameters at least four times a year. Spring discharges and level of groundwater belong to quantitative parameters. Dissolved oxygen, $\mathrm{pH}$ value, electrical conductivity, nitrates, turbidity and microbiological composition belong to qualitative parameters. It is very important to include all institutions that are the direct users of these resources, especially water supply system, industry and institutes for public health, and ensure the good cooperation and communication between them.

\section{REFERENCES}

EU Water Framework Directive WFD 2000/60: Directive 2000/60/EC of the European Parliament and of the Council establishing a framework for the Community action in the field of water policy. Official Journal of EU, L 327/1, 22 December 2000, Brussels.

Poledica M., 2015. Predlog nove osmatračke mreže vodnih tela karstnih podzemnih voda u zapadnoj Srbiji. Univerzitet u Beogradu, Rudarsko-Geološki Fakultet, Beograd [final thesis].

Stevanović D., 2015. Predlog nove osmatračke mreže vodnih tela karstnih podzemnih voda u istočnoj Srbiji. Univerzitet u Beogradu, Rudarsko-Geološki Fakultet, Beograd [final thesis].

Stevanović Z., 2011. Menadžment podzemnih vodnih resursa. Univerzitet u Beogradu, Rudarsko-Geološki Fakultet, Beograd. 